\title{
Professional Activities of the European Taekwondo Coach: A Comparative Analysis
}

\author{
Zbigniew BUJAK ${ }^{1}$ Dariusz GIERCZUK ${ }^{1}$ \\ Iris $\mathrm{ORBACH}^{2} \bullet$ Boris BLUMENSTEIN ${ }^{2,3}$
}

\begin{abstract}
The purpose of this manuscript is to establish and compare the basic professional activities that are important for successful performance of taekwondo coaches from Poland and several other European countries. Fifty-nine high level taekwondo coaches were divided into two groups: Group A included 31 European coaches from seven countries and Group B included 28 Polish coaches. Participants were asked to respond by e-mail to a questionnaire that included a list of 20 basic coaches' professional activities. Results revealed that managing physical and technical preparation and planning the process of preparing competitiors are important for suceess in taekwondo for both groups. Moreover, differences in professional coach's activities are discussed.
\end{abstract}

Keywords: professional activity, taekwondo, coach education

${ }^{1}$ Department of Combat Sport and Weightlifting, University of Physical Education in Warsaw, Branch in Biała Podlaska, Poland

${ }^{2}$ Ribstein Research Center, Wingate Institute, Israel

${ }^{3}$ Givat Washington Academic College, Israel 


\section{Introduction}

The coach plays an important role within the training process. In the course of long-term training coaches perform a number of professional activities whose type, range, and intensity lead either to success or to the lack of it. Gilberta and Trudel (2004) reviewed over 600 publications regarding coaches in Englishlanguage journals from the period 1970-2001. They found that the specificity principle in sport requires that the coach possess particular knowledge, skills, and individual characteristics that are specific to the coaching context. In addition, coach's professional preparation - including coaching behaviour, attitudes of coaches, and sources of their knowledge - as well as coaching models, have been analysed by various researchers (e.g., Bloom, 2002; Blumenstein, Lidor, \& Tenenbaum, 2005; Cushion, Armour, \& Jones, 2006; Cushion, Armour, Robyn, \& Jones, 2003; Irwin, Hanton, \& Kerwin, 2004; Jones, Armour, \& Potrac, 2002; Knowles, Borrie, \& Telfer, 2005; Lyle, 2002; Potrac, Brewer, Jones, Armour, \& Hoff, 2000; Renshaw, Keith, \& Shuttleworth, 2009). In the majority of the publications the issue of coaches' professional preparation was discussed. Blumenstein, Orbach, Bar-Eli, Dreshman, and Weinstein (2012) distinguished 250 factors associated with the specificity of coaching work according to coaches' perception. In addition, Tumanian (1985) suggested 19 basic types of activities that characterize the coaching profession. These types were later developed into 20 professional coaching activities (Sterkowicz, Gracia, \& Lerma, 2007). The literature review shows that this methodology-based approach is not common in all countries, which may stem from the fact that coaches from Western countries can be cautious and distrustful of coaching solutions coming from socialist countries (Blumenstein, 2001; Lyle, 2002).

Knowledge of the theory and methodology of sport training is accessible in the literature (e.g., Bompa, 1999). Potential champions might be everywhere (naturally gifted or hard-working athletes), and training conditions in particular countries are similar (Lyle, 2002; Smith, 2003). Nonetheless, only a very few attain success. Determining the structure of the most significant coaching activities may help to solve the problem of how to train athletes more rationally, optimally, and, first and foremost, effectively. Regardless of his/her objectives, the coach is always one of the most significant factors of the training structure (Lyle, 2002; Martens, 2004).

Sports achievements give rise to questions on training methods, organisational solutions, and the preparation of coaches. Repeatability of successful results might be the outcome of an applied training system combined with a coach's analytical and experimental approach to tasks. For many years Polish coaches have been able to prepare their high level taekwondo athletes for 
success in the most important competitions, as evidenced by the European and World Championship results. Since 1994 the Polish competitors have been the best in Europe and since 1999 they have been among top world athletes. For example, in 2013-2014 Polish taekwondo athletes achieved 75 medals in Senior European and World championships (Bujak, 2014; Bujak \& Gierczuk, 2013). The question regarding how such high competition effectiveness is achieved remains unanswered. At its basis, taekwondo was directed to the Korean society as a way of strengthening body and mind as well as enhancing national identity (Choi, 1965; Gillis, 2011). Its dynamic development and the commencement of the so-called intensive and prestigious period caused taekwondo officials to pay more attention to training (Ważny, 1981). As a result, professional (Olympic) taekwondo came into being. The search for an effective training process led to a greater interest in professional activities and the competence of the coach as the basic and most crucial link of the whole chain of correlations (Bujak, 2000; Bujak \& Gierczuk, 2013; Bujak, Muntean, \& Gierczuk, 2014).

The aim of this study was to establish the rank of basic professional activities of taekwondo coaches from Poland and other European countries. Moreover, a comparison of coaches' activities, including identifying clusters of activities on the basis of interrelations, was conducted.

\section{Method}

\section{Participants}

Fifty-nine high level taekwondo male coaches were participated in this study (Table 1). Participants were divided into two groups: Group A included 31 European coaches $(\mathrm{M} a g e=40.4 ; \mathrm{SD}=6.45)$ from seven countries (Hungary, Italy, Luxembourg, Ireland, Belgium, Slovakia, and Norway). Group B was made up of 28 Polish coaches (Mage=35.1, SD=7.93).

\section{Instruments}

Information regarding the coaches' age, years of training experience as athletes, years of coaching experience, and level of technical preparation was collected. The level of technical preparation was transformed into points according to the following scale: I dan $=56$ pts; II dan $=68$ pts, III dan $=83$ pts; IV-VII dan $=100$ pts (Bujak, 2000).

A questionnaire containing a list of 20 basic activities performed by the coach was given to the participants, who rated the activities on a scale as follows: 1 - very important, 2 - important, 3 - less important, 4 - not important 
(Sterkowicz et al., 2007). The questionnaire's statistical results regarding validity and reliability were published by Sterkowicz (1999).

\section{Procedure}

The Polish Taekwondo association sent the questionnaire by e-mail to the local Polish coaches and to the European national Taekwondo associations. Responses to the questionnaire were received after approximately two weeks from 28 local Polish coaches and 31 European coaches from seven countries.

\section{Data analysis}

Statistics including mean values (M), standard deviations (SD), coefficients variation $(\mathrm{CV})$, weighted means, and t-tests were utilized. In addition, a cluster analysis was conducted using the agglomeration method by the Statistica 6.0 program.

\section{Results}

The greatest differences between participants concerned the length of their coaching experience. These differences were extremely large in the case of the Polish coaches $(\mathrm{CV}=77 \%)$. The groups were significantly different in age $(\mathrm{p}<.01)$, training, and coaching experience $(\mathrm{p}<.001)$, as well as the level of technical preparation $(\mathrm{p}<.001)$.

Table 1

Characteristics of participants $(n=59)$

\begin{tabular}{|c|c|c|c|}
\hline Variable & Statistics & Gr. A $(n=31)$ & Gr. B $(n=28)$ \\
\hline \multirow{2}{*}{ Age $($ years)** } & $\mathrm{M} \pm \mathrm{SD}$ & $40.4 \pm 6.45$ & $35.1 \pm 7.93$ \\
\hline & $\mathrm{CV}$ & $15.9 \%$ & $22.6 \%$ \\
\hline \multirow{2}{*}{ Training experience (years) ${ }^{* * *}$} & $\mathrm{M} \pm \mathrm{SD}$ & $25.2 \pm 5.30$ & $19.2 \pm 6.63$ \\
\hline & $\mathrm{CV}$ & $21.0 \%$ & $34.5 \%$ \\
\hline \multirow{2}{*}{ Coaching experience (years) ${ }^{* * *}$} & $\mathrm{M} \pm \mathrm{SD}$ & $17.8 \pm 5.84$ & $10.0 \pm 7.74$ \\
\hline & $\mathrm{CV}$ & $32.8 \%$ & $77.4 \%$ \\
\hline \multirow{2}{*}{ Level of technical preparation $(\mathrm{pkt})^{* * *}$} & $\mathrm{M} \pm \mathrm{SD}$ & $97.3 \pm 7.46$ & $82.6 \pm 13.70$ \\
\hline & $\mathrm{CV}$ & $7.7 \%$ & $16.6 \%$ \\
\hline
\end{tabular}

Note: $* * \mathrm{p}<.01 ; * * * \mathrm{p}<.001$ 
The similarities and differences of taekwondo coaches' activities from Poland and other European countries are presented in Table 2. The results revealed slightly different opinions concerning the significance of particular professional coaching activities (see Table 2). For example, both groups selected "managing technical preparation" as the most important activity (rank 1). However, Group A selected "managing tactical preparation" as a less important activity (rank 8) as compared to Group B (rank 2).

Table 2

The rank of basic professional coaching activities for successful performance in taekwondo

\begin{tabular}{llccccccc}
\hline \multirow{2}{*}{ No } & \multirow{2}{*}{ Coach's activities } & \multicolumn{3}{c}{ Group A (Europe) } & \multicolumn{2}{c}{ Group B (Poland) } \\
\cline { 3 - 8 } & & $\mathrm{M}$ & $\mathrm{SD}$ & $\mathrm{Rank}$ & $\mathrm{M}$ & $\mathrm{SD}$ & Rank \\
\hline 1 & Managing physical preparation & 1.52 & 0.57 & 2 & 1.36 & 0.49 & 3 \\
2 & Managing tactical preparation & 1.71 & 0.68 & 8 & 1.25 & 0.44 & 2 \\
3 & Managing technical preparation & 1.29 & 0.64 & 1 & 1.18 & 0.39 & 1 \\
4 & Managing volitional preparation of competitors & 1.74 & 0.63 & 9 & 1.68 & 0.61 & 6 \\
5 & Managing theoretical preparation of competitors & 1.84 & 0.52 & 11 & 2.04 & 0.69 & 13 \\
6 & Managing athletes during competitions & 1.65 & 0.8 & 5 & 1.82 & 0.72 & 8 \\
7 & Controlling a training process and the state of the athlete's body & 1.74 & 0.63 & 9 & 1.46 & 0.58 & 4 \\
8 & Supervising the progress of athletes at school & 2.23 & 0.67 & 17 & 2.43 & 0.84 & 18 \\
9 & Organising and refereeing competitions & 2.07 & 0.73 & 14 & 2.69 & 0.72 & 20 \\
10 & Organising sports camps & 2.19 & 0.87 & 16 & 2.29 & 0.53 & 16 \\
11 & Organising educational work in a group & 2.23 & 0.72 & 17 & 1.96 & 0.64 & 12 \\
12 & Organising the processes of recovery and relaxation & 2.61 & 0.62 & 20 & 1.86 & 0.59 & 10 \\
13 & Planning the process of preparing competitors & 1.65 & 0.66 & 5 & 1.46 & 0.51 & 4 \\
14 & Improving the manners of competitors & 1.68 & 0.65 & 7 & 1.89 & 0.57 & 11 \\
15 & Conducting research for scientific and methodological papers & 2.07 & 0.68 & 14 & 2.61 & 0.63 & 19 \\
16 & Keeping record and reporting & 2.23 & 0.76 & 17 & 2.36 & 0.62 & 17 \\
17 & Recruiting and selecting candidates for training groups & 1.9 & 0.83 & 13 & 1.68 & 0.61 & 6 \\
18 & Preparing instructors and referees & 1.52 & 0.72 & 2 & 2.04 & 0.84 & 13 \\
19 & Solving organisational problems related to training & 1.84 & 0.73 & 11 & 1.75 & 0.59 & 8 \\
20 & Providing first aid & 1.55 & 0.68 & 4 & 2.11 & 1.07 & 15 \\
\hline & & & & & & &
\end{tabular}


The five most important activities marked by taekwondo coaches from other European countries (group A) were managing technical preparation of competitors (rank 1); managing physical preparation (rank 2) and preparing instructors and referees (rank 2); providing first aid (rank 4); managing athletes during competition (rank 5), and planning the process of preparing competitors (rank 5) (see Table 3).

The following five activities were considered by the European taekwondo coaches as less important: Organising the process of recovery and relaxation (rank 20); supervising the progress of athletes at school (rank 17), organising educational work in a group (rank 17), and keeping records and reporting (rank 17); organizing sport camps (rank 16). The opinions on the ranking of the most important activities were more diverse $(\mathrm{CV}=38-50 \%)$ than in the case of less important ones $(\mathrm{CV}=24-34 \%)$.

Table 3

The five more/ less important activities as reported by taekwondo coaches

\begin{tabular}{|c|c|c|c|}
\hline \multirow{2}{*}{ Rank } & Group A (Europe) & Group B (Poland) & \multirow{2}{*}{ Rank } \\
\hline & Coach's activities & Coach's activities & \\
\hline 1 & Managing technical preparation & Managing technical preparation & 1 \\
\hline 2 & Managing physical preparation & Managing tactical preparation & 2 \\
\hline 2 & Preparing instructors and referees & Managing physical preparation & 3 \\
\hline 4 & Providing first aid & $\begin{array}{l}\text { Controlling a training process and the } \\
\text { state of the athlete's body }\end{array}$ & 4 \\
\hline 5 & $\begin{array}{l}\text { Managing athletes during } \\
\text { competition }\end{array}$ & $\begin{array}{l}\text { Planning the process of preparing } \\
\text { competitors }\end{array}$ & 4 \\
\hline 5 & $\begin{array}{l}\text { Planning the process of preparing } \\
\text { competitors }\end{array}$ & & \\
\hline 16 & Organizing sports camps & Organizing sports camps & 16 \\
\hline 17 & $\begin{array}{l}\text { Supervising the progress of athletes } \\
\text { at school }\end{array}$ & Keeping records and reporting & 17 \\
\hline 17 & $\begin{array}{l}\text { Organising educational work in a } \\
\text { group }\end{array}$ & $\begin{array}{l}\text { Supervising the progress of athletes } \\
\text { at school }\end{array}$ & 18 \\
\hline 17 & Keeping records and reporting & $\begin{array}{l}\text { Conducting research for scientific and } \\
\text { methodological papers }\end{array}$ & 19 \\
\hline 20 & $\begin{array}{l}\text { Organizing the process of recovery } \\
\text { and relaxation }\end{array}$ & $\begin{array}{l}\text { Organizing and refereeing } \\
\text { competitions }\end{array}$ & 20 \\
\hline
\end{tabular}


The five most important activities marked by taekwondo coaches from Poland (group B) were managing technical preparation of competitors (rank 1); managing tactical preparation (rank 2); managing physical preparation (rank 3); controlling a training process and the state of the athlete's body (rank 4), and planning the process of preparing competitors (rank 4).

In addition, the following five activities were considered by the Polish taekwondo coaches as least important: Organising and refereeing competitions (rank 20); conducting research for scientific and methodological papers (rank 19); supervising the progress of athletes at school (rank 18); keeping records and reporting (rank 17); organizing sport camps (rank 16). The coaches' opinions were less diverse in the case of the least important activities $(\mathrm{CV}=24-34 \%)$ than in the most important ones $(\mathrm{CV}=33-39 \%)$.

A comparison between the two groups in reference to coach's activities as listed in the questionnaire revealed interesting results (see Figure 1). Significant differences between the two groups were found in six professional activities $(\mathrm{p}<.05-.001)$. According to the Polish taekwondo coaches, by far the most important activities were managing the tactical preparation of competitors (difference of 6 ranks) and organising the process of recovery and relaxation (difference of 10 ranks). In turn, the coaches from other European countries claimed that the following activities were far more important: organising and refereeing competitions (difference of 6 ranks), conducting research for scientific and methodological papers (difference of 5 ranks), preparing instructors and referees (difference of 11 ranks), and providing first aid (difference of 11 ranks). Managing technical preparation was selected as the most important coaching activity by both groups. Other activities on which participants expressed similar opinions included managing volitional preparation of competitors, organising sports camps, and solving organisational problems related to training. The differences regarding the significance of basic coaching activities in taekwondo showed that the concurrence of opinions was at a moderate level $(\mathrm{rSp}=.56$; $\mathrm{p}<.01)$. 


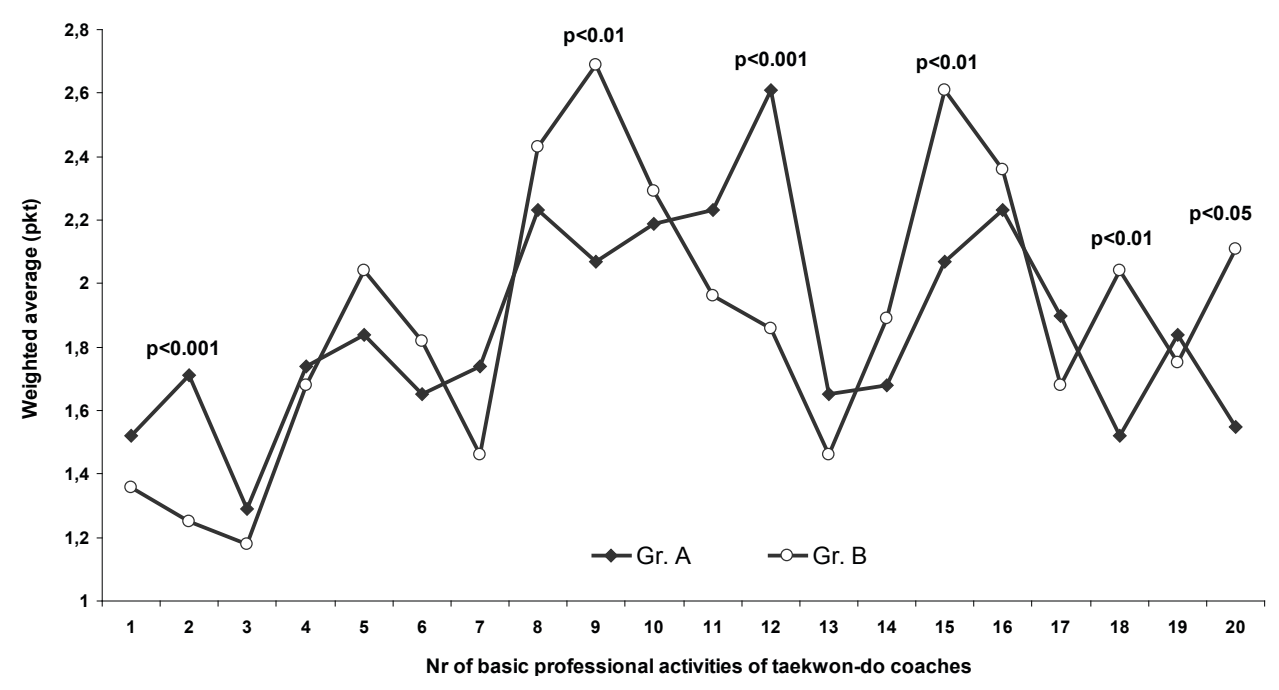

Figure 1. Comparison of the significance of professional coaching activities in taekwondo (based on Table 2) according to Polish and European coaches' responses

A taxonomic analysis of the European coaches' responses helped to distinguish three groups of activities clustered together (see Figure 2). The first group consisted of eight activities ranked between 1 and 12. The second group was composed of seven activities, while the third one included five activities. The strongest correlations were noted between managing volitional preparation (rank 9) and managing theoretical preparation of competitors (rank 11). 


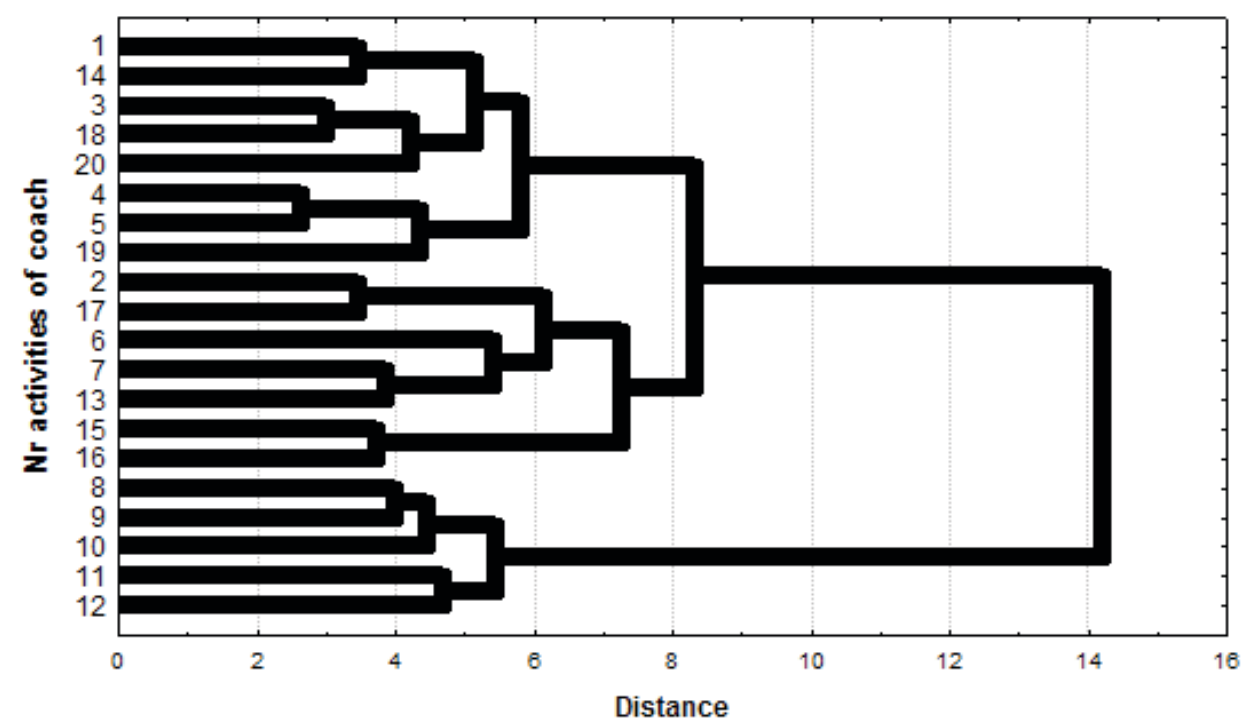

Figure 2. Dendrogram of basic professional activities (based on Table 2) according to European taekwondo coaches

Similar to European coaches, data regarding Polish coaches indicated three groups of activities clustered together which consisted of different professional activities (see Figure 3). The first cluster included three activities ranked from 1 to 3 . The second cluster consisted of nine activities, whereas the third one was composed of eight activities. The strongest correlation was observed between managing physical preparation (rank 3) and managing technical preparation of competitors (rank 1). 


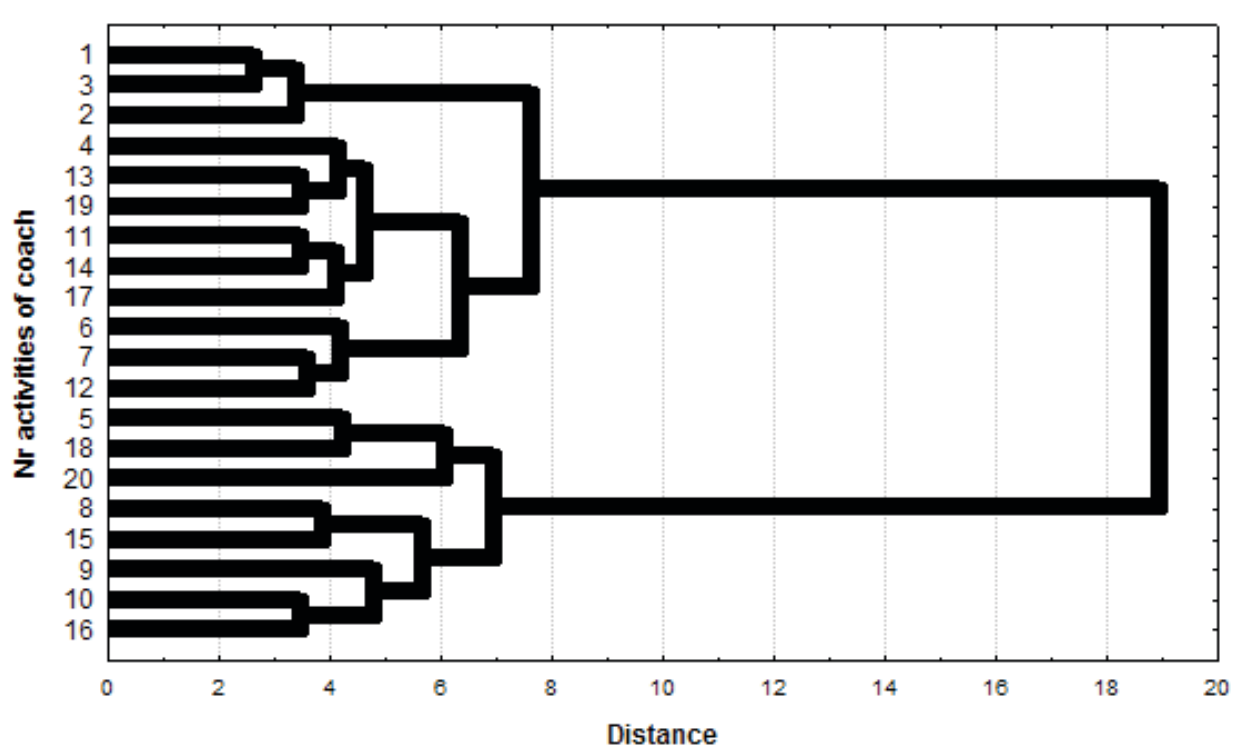

Figure 3. Dendrogram of basic professional activities (based on Table 2) according to Polish taekwondo coaches

\section{Discussion and Conclusions}

The aim of the study was to establish similarities and differences between basic professional activities of taekwondo coaches from Poland and from other European countries. This comparison should help to identify dominant coach's activities which, according to the respondents, determine sports success. Research findings show that managing technical and physical preparation of competitors is an extremely important coaching activity in combat sports as well as in other sports (Bloom, 2002; Blumenstein et al. 2005; Bujak et al., 2014; Sterkowicz et al., 2007). Similarly, the Polish and the European taekwondo coaches reported that managing physical preparation, technical preparation, and planning the process of preparing competitors are all important for successful performance in taekwondo.

When comparing the opinions of taekwondo coaches, however, it seems that training effectiveness is based on four aspects: (1) tactical preparation, (2) controlling a training process and the state of the athlete's body, (3) organising the process of recovery and relaxation, and (4) organising educational work in a group. 
First, tactical preparation in taekwondo can include a sparring event, preparation before competition, or even preparation during an athlete's entire career. Tactics as a component of operational strategy ought to include both shorter and longer periods of training based on reasonable planning and regular control (Bloom, 2002; Norris \& Smith, 2002; Zaryski \& Smith, 2005).

Second, controlling post-training effects and the training process is another significant factor that differentiates between the two groups. Apart from the coaching supervision during training sessions and competitions, controlling the training process in taekwondo mainly involves assessing technical preparation. This is done by means of proper exams as well as analysing achievements in competitions at various levels and in selected motor tests (Pieter \& Heijmas, 2000; Santos, Franchini, \& Lima-Silva, 2011). Modern technology applied in competition makes it possible to record and analyse various tactical solutions and to gain competitive experience, as well as to recognise various behaviours in extremely difficult situations. If a competitor who is under the pressure to win abides by the rules and regulations, he/she will surely act reasonably under less stressful circumstances. Thus, discipline and self-discipline imposed and controlled by a coach exerts a positive educational influence (Lakes \& Hoyt, 2004; Trulson, 1986).

Third, in elite sport, recovery and relaxation are treated as significant factors in the modern training process (Blumenstein et al., 2012; Bompa, 1999; Kenta \& Hassmen, 1998). Taekwondo coaches use their knowledge and capabilities to implement different procedures, but with no specific guidelines or standards in this aspect. Recovery and relaxation ought to become an indispensable part of the training process.

Fourth, it seems that attaching too much importance to organising educational work in a group, refereeing competitions, preparing instructors and referees, and providing first aid can hinder or prevent the achievement of considerable success in taekwondo. At the same time, it is difficult to clearly define the significance of conducting research for scientific and methodological papers in the structure of coaching activities. Various activities are connected with the scientific cognition of reality. However, we should not expect coaches to possess the same amount of knowledge as scientists and researchers (Lyle, 2002). The study by Blumenstein and Orbach (2010) revealed that experts and other coaches did not differ in personality traits and knowledge, but they did differ in 10 skills such as positive attitude, self-demand and openness to cooperation. Taekwondo coaches should demonstrate such qualities as responsibility, leadership, innovativeness, and problem-solving skills. Coaching effectiveness requires relying on one's own experience and knowledge, not just copying others 
uncritically (Feltz, Chase, Moritz, \& Sullivan, 1999). Modern sports' training is endorsed by multidisciplinary expert (declarative and procedural) knowledge from which the best coaches can benefit (Abraham \& Collins, 1998).

To summarize, the research findings made it possible to draw the following conclusions. There are unique basic professional coaching activities that may distinguish taekwondo coaches who achieve success from others. In addition, basic professional coaching activities clustered together in a natural way facilitate planning the work in successive cycles, as well as preparing strategy regarding the entire sports careers of taekwondo competitors.

In the training process of taekwondo, some activities should be put together and taken into consideration in training plans and practical solutions. Therefore, it is recommended that particular professional activities be included in the educational programs of taekwondo coaches.

\section{References}

Abraham, A., \& Collins, D. (1998). Examining and extending research in coach development. Quest, 50(1), 59-79.

Bloom, G. (2002). Coaching demands and responsibilities of expert coaches. In J. M. Silva, \& D. Stevens (Eds.). Psychological foundations of sport (pp. 438-465). Boston, MA: Allyn and Bacon.

Blumenstein, B. (2001). Sport psychology practice in two cultures: Similarities and differences. In G. Tenenbaum (Ed.), The practice of sport psychology (pp. 231240). Morgantown, WV: Fitness Information Technology.

Blumenstein, B., Lidor, R., \&Tenenbaum, G. (2005). Periodization and planning of psychological preparation in elite combat sport programs: The case of judo. International Journal of Sport and Exercise Psychology, 3(10), 7-25.

Blumenstein, B., \& Orbach, I. (2010). The profile of the professional coach. Applied Research in Coaching and Athletics Annual, 25, 213-230.

Blumenstein, B., Orbach, I., Bar-Eli, M., Dreshman, R., \& Weinstein, Y. (2012). High-level coaches' perceptions of their professional knowledge, skills, and characteristics. Sport Science Review, 21(5-6), 5-27. 
Bompa, T. (1999). Periodization: Theory and methodology of training (4 ${ }^{\text {th }}$ ed.). Champaign, IL: Human Kinetics.

Bujak, Z. (2000). Physical development and fitness of taekwondo competitors. In R. M. Kalina, K. Klukowski, K. Jędrzejak, \& A. Kaczmarek (Eds.). Contemporary directions of physical culture development in uniformed services (pp. 39-46). AWF: Warsaw, Poland. (in Polish)

Bujak, Z. (2014). Model sprawnosci fizycznej I specjalnych umiejetnosci ruchowych zawodnikow taekwondo na kolejnych etapach zaawansowania. Biala Podlaska, Poland. (in Polish)

Bujak, Z., \& Gierczuk, D. (2013). Professional activities of an Olympic martial sports trainer. Physical Activity Review, 1, 50-58.

Bujak, Z., Muntean, M. V., \& Gierczuk, D. (2014). The hierarchy of professional activities of martial arts and mixed martial arts coaches: IDO movement for culture. Journal of Martial Arts Anthroplogy, 14(2), 29-35.

Choi, H. H. (1965). Taekwondo: The art of self-defense. Seoul, Korea.

Cushion, C. J., Armour, K. M., \& Jones R. L. (2006). Locating the coaching process in practice: Models 'for' and 'of' coaching. Physical Education and Sport Pedagogy, $11(1), 83-99$.

Cushion, C. J., Armour K. M., Robyn, L., \& Jones, R. L. (2003). Coach education and continuing professional development: Experience and learning to coach. Quest, 55(3), 215-230.

Feltz, D. L., Chase M. A., Moritz, S. E., \& Sullivan, P. J. (1999). A conceptual model of coaching efficacy: Preliminary investigation and instrument development. Journal of Educational Psychology, 91(4), 765-776.

Gilberta, W. D., \& Trudel, P. (2004). Analysis of coaching science research published from 1970-2001. Research Quarterly for Exercise and Sport, 75(4), 388399.

Gillis, A. (2011). A killing art: the untold history of taekwondo. ECW Press, Toronto, Ca.

Irwin, G., Hanton, S., \& Kerwin D. (2004). Reflective practice and the origins of elite coaching knowledge. International and Multidisciplinary Perspectives, 5(3), 425-442. 
Jones, R. L., Armour, K. M., \& Potrac, P. (2002). Understanding the coaching process: A framework for social analysis. Quest, 54(1), 34-48.

Kenta, G., \& Hassmen, P. (1998). Overtraining and recovery. Sports Medicine, 26(1), 1-16.

Knowles, Z., Borrie, A., \& Telfer, H. (2005). Towards the reflective sports coach: issues of context, education and application. Ergonomics, 48(11-14), 1711 1720.

Lakes, K. D., \& Hoyt, W. T. (2004). Promoting self-regulation through schoolbased martial arts training. Applied Developmental Psychology, 25, 283-302.

Lyle, J. (2002). Sports coaching concepts: A framework, for coaches' behavior. London, UK: Routledge.

Martens, R. (2004). Successful coaching (3rd ed.). Champaign, IL: Human Kinetics.

Norris, S. I., \& Smith, D. J. (2002). Planning, periodization, and sequencing of training and competition: the rationale for a competently planned, optimally executed training and competition program, supported by a multidisciplinary team. In M. Kellmann (Ed.), Enhancing recovery: Preventing underperformance in athletes (pp. 121-141). Champaign, IL: Human Kinetics.

Pieter, W., \& Heijmans, J. (2000). Scientific coaching for Olympic taekwondo. Aachen, Germany: Meyer \& Meyer Sport.

Potrac, P., Brewer, C., Jones, R., Armour, K., \& Hoff, J. (2000). Toward an holistic understanding of the coaching process. Quest, 52(2), 186-199.

Renshaw, I., Keith, W. D., \& Shuttleworth, R. (2009). Insights from ecological psychology and dynamical systems theory can underpin a philosophy of coaching. International Journal of Sport Psychology, 40(4), 580-602.

Santos, V., Franchini, E., \& Lima-Silva, A. (2011). Relationship between attack and skipping in taekwondo contests. Journal of Strength \& Conditioning Research, 25(6), 1743-1751.

Smith, D. J. (2003). A framework for understanding the training process leading to elite performance. Sports Medicine, 33, 1103-1126. 
Sterkowicz, S. (1999). Czynnosci zawodowe trenera judo. In S. Sterkowicz (Ed.), Caynnosci zawodowe trenera w sportach walki (pp. 5-8). AWF, Krakow: Poland. (in Polish)

Sterkowicz, S., Gracia, J. M., \& Lerma F. S. (2007). The importance of judo trainer's professional activities. Archives of Budo, 3, 57-61.

Trulson, M. E. (1986). Martial arts training: A novel "cure" for juvenile delinquency. Human Relations, 39, 1131-1140.

Tumanian, G. S. (1985). O nowom kompleksie ucziebnych disciplin dla kafiedr FK wypuskajuszczich trienierow - priepodawatieliej po widu sporta, Teorija $i$ praktyka fiziczeskoj kultury, 12, 36-38. (in Russian)

Ważny, Z. (1981). Contemporary training system in professional sport. SiT: Warsaw, Poland.(in Polish)

Zaryski, C., \& Smith, D. J. (2005). Training principles and issues for ultraendurance athletes. Current Sports Medicine Reports, 4(3), 165-170.

Dr. Zbigniew BUJAK is an assistant professor in the Department of Combat Sport and Weightlifting at the University of Physical Education in Warsaw, Branch in Biała Podlaska, Poland. He is a Master class coach in taekwondo and the Vice President of the Polish Taekwondo Association. His ongoing research includes injuries (traumatism), coaching activities, optimization of training in taekwondo (ITF), martial arts and combat sports.

Dr. Dariusz GIERCZUK is an assistant professor in the Department of Theory of Sport at the University of Physical Education in Warsaw, Branch in Biała Podlaska, Poland. He is a 1st class coach in wrestling. In 2006 he was awarded the Golden Star of the Polish Association of Wrestling. His ongoing research includes optimization of training process in combat sports.

Dr. Iris ORBACH is a researcher and a sport psychology consultant in the Department of Behavioral Sciences at the Ribstein Center for Sport Medicine Sciences and Research, Wingate Institute, Israel. In addition to teaching, Dr. Orbach has published two books and numerous articles and book chapters. Her current research interests include stressperformance relationships, children and motivation in sport, and the effectiveness of various mental training practices. Dr. Orbach uses her psychology skills as a consultant for athletes at all skill levels. E-mail address: iriso@wingate.org.il 
Dr. Boris BLUMENSTEIN is an associate professor in Givat Washington Academic College and the Director of the Department of Behavioral Scie nces at the Ribstein Center for Sport Medicine Sciences and Research, Wingate Institute, Israel. His research focuses on the mental skills training for enhanced performance, stress-performance relationships, the effectiveness of different mental interventions, and athletic competition readiness. He has published six books, 17 book chapters and approximately 80 refereed journal articles.

Prof. Boris Blumenstein

Ribstein Center for Sport Medicine Sciences and Research

Wingate Institute

Netanya 42902

Israel

Fax: +972-9-8639412

E-mail: borisb@wingate.org.il 